\title{
Defendable Agricultural Boost by Profiteering Endophytes
}

\author{
Premalatha Ramasamy ${ }^{1}$, Yuvarani Sethuram¹, Usha Nandhini Selvaraj ${ }^{1}$, \\ Durgha Srinivasan $^{1}$ and Vijayaraghavan Ramasamy ${ }^{2 *}$
}

\author{
${ }^{1}$ Department of Microbiology \& Biochemistry, Nadar Saraswathi College of Arts \& Science, \\ Theni, Tamilnadu, India \\ ${ }^{2}$ Department of Biotechnology, Nehru college of Arts and Science, Coimbatore, India \\ *Corresponding author
}

\section{A B S T R A C T}

\begin{tabular}{|l|}
\hline K e y w o r d s \\
Endophytes, \\
Sterilization, PCR, \\
Molecular \\
characterization
\end{tabular}

Endophytes are the organisms that live within plant tissues and spend at least a half of their life time without causing disease under any circumstances. So, the endophytes are commonly defined as those organisms whose infections are inconspicuous and symptomless in host tissue and internal microbial colonization. Both prokaryote (bacteria) and eukaryotes (fungi) colonize the plant tissues exhibiting a little variation in their colonization mode. The former colonize intracellularly in vascular tissues and the later shows asymptomatic colonization either inter or intracellularly. It has been indicated that endophytes protect plants against pest attack and make them evolve molecular mechanism to face the challenges. The various climatic conditions including global warming, drought stress and deforestation are found to affect the cellular compartments, mutualistic interactions, etc. The successful isolation of endophytes relies on effective surface sterilization. Studies have also been made on the molecular characterization of endophytes including metagenomic studies, molecular markers, molecular cloning, etc. The future studies at molecular levels warranted to ascertain the protective role of PGPB against fungal pathogens.

\section{Introduction}

Plants are the major contributors in fixing atmospheric $\mathrm{CO}_{2}$ on earth. The photo energy from sunlight enables the plants in reducing carbon in $\mathrm{CO}_{2}$ and produces the wide range of carbonaceous compounds. The diverse microorganisms are normally associated with plants and animals. In animals, the bacterial flora present in the gut region has made a remarkable role in stimulating immunity (Hooper et al., 2011). Similarly in plants, the bacteria play a significant role in plant defense responses (De Matos Nogueira et al., 2001).

Numerous bacteria and fungi thrive on plant surfaces are called epiphytes. Certain microbes grow intimately with the plant hosts which influence plant metabolism hormonal pathways in addition to regular nutritional and biosynthetic capacities. Many of the phenotypic properties of plants are derived from the plant - microbe interaction. These naturalistic traits of microbes influence plants' interaction with competitors, 
mutualists, pathogens and can play a role in growth, productivity and nutrient fluxes (Maren L. Friesen et al., 2011).

\section{Endophytes}

Plants harbor diverse communities of microorganisms like fungi and bacteria. These organisms are known to occur on plant surfaces called epiphytes and those present inside the plant tissues are endophytes. A Range of microorganisms including fungi, bacteria, virus and complex interaction are found within the plant tissues. As Hyde and Soy Tong (2008) mentioned, there is a doubtful series of definitions to describe an endophyte. De Bary (1866), defined endophytes as any organisms occurring within plant tissues.

Recent reviews of bacterial and fungal endophytes recommend that the term endophyte should refer to "habitat only and not function" and should include the microbes which colonize internal plant tissues for all or a part of their life cycle (Hallmann et al., 2001, Schulz and Boyle, 2005).

The above said definition found to be similar to that of Hallmann et al., (1997), but considers all contributing microbes. "Endophytes are microbes which occur within plant tissues for at least part of their life time without causing disease under any known circumstances."

This statement explains that certain microorganisms which are considered endophytes in beginning may be changed to harmful. It is observed that the genomes of fungi considered as endophytes often possess plant pathogenic genes. Endophytes promote the growth and yield of plants, suppress pathogens by removing contaminants, involve in $\mathrm{PO}_{4}$ solubilization and nitrogen fixation to plants.

\section{History}

Endophytes were first described by the German Botanist Heinrich Friedrich Link in 1809. Endophytes are termed as "microzymas" by the French scientist BeChamp. Until 1887, it was believed that plants were healthy under sterile conditions, after which it was discovered that bacteria occur inside the plants tissues (Victor Galippe, 1887)

The world 'endophyte' is derived from Greek word ("Endon" =within, "Phyton" =plant) which literally means "within the plant". The usage of this term is as board as its literal definition and spectrum of potential hosts and inhabitants. Although there are diverse uses for the word endophyte, they are most commonly defined as those organisms whose infections are inconspicuous, symptomless in host tissue and internal microbial colonisation (Stone et al., 2000).

In spite of the fact that bacteria are prokaryotes and fungi are eukaryotes, they share many attributes of their association with plant hosts e.g. both colonize root tissues inter and intra-cellularly and often systemically. However, they show a little variation in their modes of colonization i.e. bacteria primarily colonies intracellularly (HallMann et al., 1997) and are frequently found in the vascular tissues of host plants (Kobayashi and Palumbo 2000). In case of fungi, asymptomatic colonization may be inter and intra-cellular throughout the root.

\section{Impact of endophytes on plants}

Generally, it is considered that the bacteria are present within plants tissues which may or may not be pathogenic. The non-pathogenic flore occur in root tissues (Perotti, 1926). Presence of bacteria was observed in leaves, stem and roots of healthy plants (Hennig and 
Vill forth, 1940). Beijerinck (1888) described the colonization of rhizobia in legume root tissues. Shekhawat et al., (1984), reported the existence of both pathogenic and nonpathogenic endophytic bacteria within potatoes and triggering of disease development by an external event. Certain bacterial species may become pathogenic under certain conditions (Hayward, 1974).

Bacterial endophytes reside inside plants for at least part of their life cycle (Hallmann et al., 1997). A series of articles indicate the benefits of selective fungal or bacterial endophytes in plant protection against pest attack.

The bacterial invasion in plants could have a major impact on growth and health of plant and the plants are supposed to evolve molecular mechanisms to deal with the challenges posed by invaded bacteria.

Severe environmental constraint to agricultural productivity is caused by drought stress. In the modern agriculture system the fertile nature of soil is often maintained by applying bio fertilizers and usage of agrochemicals has been increased to control pathogens and pests.

\section{Effect of climate on endophytes}

The population of endophytes varies from plant to plant, species to species and also the same species from one region to other. The variation also occurs with change in climatic condition of same region. In total endophytic fungi, the temporal changes in relative frequency were studied (Chareprasert et al., 2006).

The additional consequences of global warming may be the effect of drought stress which on AMF has been reviewed thoroughly by Auge (2001). The multidimensional stress drought affects various sub cellular compartments, cell organs and the whole plant level (Choluj et al., 2004, Rahadari et al., 2012). So the quantity and quality of growth in plants is negatively affected due to drought. The migration of drought stress is necessary to achieve designated goals to increase the food production.

Drought is often responsible for plant growth reduction and it also affects both root and aerial plant parts. This causes changes not only in allocation of photosynthates in the rhizosphere but also in extra mycorrhizal mycelia formation. Drought does not affect the density of extra mycorrhizal hyphae as demonstrated with Glomus sp. But under drought condition more hyphae were produced when expressed relative to root length (Staddon et al., 2004). This may be explained by the fact that part of mycelium might be dead (Staddon et al., 2003) and so before drought most hyphae have been produced (Staddon et al., 2004).

Some endophytes are seen to be the latent pathogens and only at certain condition the infection proceeds. This occurs due to the environmental conditions such as $\mathrm{CO}_{2}$ accumulation or $\mathrm{O}_{2}$ depletion (Lund and Whyatt, 1972)

The greater number of genera and species with higher colonization frequency were found in matured leaves of teak (Tectone grandis L) and rain tree (Samanea saman) than those in young leaves. During rainy season their occurrence in leaves increased. The endophytic population and frequency tended to differ among sampling dates for all organs studied, namely young petioles and twigs of Gingko biloba (Thongsandee et al., 2012) The temperature stress in plants is alleviated by some rhizosphere bacteria and endophytes and these strains induce the growth promotion of different crops at 
different climates, soil, temperature (Bilal et al., 1993, Javed and Arsha, 1997).

Endophytes play a major role in mutualistic interactions, enhancing host plant's nutrient uptake and helping host to counteract adverse effects of biotic and abiotic stress (Idris et al., 2007).

While comparing with rhizospheric bacteria or bacterial pathogens, the endophytic bacteria occur at lower population densities (Hallmann et al., 1997; Rosenblueth and Mastineze Romero, 2004) Endophytic population like rhizospheric population is conditioned by biotic and abiotic factors (Seghers et al., 2004) When compared to rhizospheric bacteria the endophytic bacteria could be better protected from biotic and abiotic stress (Hallmann et al., 1997)

Egamberdiyeva and Hoflich (2003) reported that temperature and soil type may affect the performance of the plant beneficial bacteria. From semi-continental climate the Mycobacterium sp. 44 and Pseudomonas fluorescens and Pantoea agglomerans were isolated and found to increase the root and shoot growth in winter wheat at $16^{\circ} \mathrm{C}$ compared with that $26^{\circ} \mathrm{C}$ in loamy sand. Rain forest destruction may lead not only to the loss of valuable tree species it also affects the unknown endophytes, especially fungi (Strobel et al., 2004).

The major role played by drought stress is it makes physico-chemical and biological properties of soil in microbial activity and crop yield. Water availability controls the production and consumption of protein and polysaccharides by the bacteria (Roberson and Firestone, 1992) and thus indirectly influence soil structure. The microbes produce Exopolysaccharide (EPS) which protects them from inhospitable conditions and enables their survival. Capsular material of A. brasilense sp 245 contain high molecular weight carbohydrate complex (Lipopolysaccharide protein (LP) complex and Polysaccharide (PL) complex responsible for the protection under extreme conditions like desiccation. These complex addition to a suspension of decapsulated cells of $A$. brasilense sp 245 significantly enhanced survival under drought stress (Konnova et al., 2001). The drought stress causes changes in plant associated communities. The different subpopulations of endophytic bacteria colonizing sunflower cultivated under drought condition (or) under irrigation management were identified recently (Forchetti et al.,2007) Under drought condition, one particular Achromobacter strain was found which indicates a better adaptation to drought stress condition. Interestingly, a higher plant growth promotion potential was found in endophytic bacteria isolated from sunflower cultivated under drought when compared with irrigated plant (Forchetti et al., 2007).

\section{Isolation of endophytes}

Both Monocotyledonous and Dicotyledonous plants contain endophytic bacterial species, ranging from woody tree species such as oak, pear to herbaceous crop plant such as sugar beet and maize (Miche and Balandreau,2001) Totally 2003 fungal endophytes were isolated from 750 surface sterilized seeds. In contrast, only 16 endophytic isolates were obtained from 800 surface sterilized seeds (J. Hallmann 1997).

The microbes such as endophytic bacteria, fungi and actinomycetes whose isolation from the plant tissue has been a challenge since the studies on endophytes begins. Several researchers have reviewed different methods of the separation of bacterial endophytes (Hallmann and Reinhold, 1998). An initial surface sterilization is used to isolate endophytes followed by culturing from 
ground tissue extract (Rai, 2007) (or by direct culturing of plant tissues on media suitable for bacteria or fungi or actinomycetes (Hata 2008).

Lodewyckx et al., (2002) review highlights the method used to isolate and characterize endophytic bacteria from various plant species. A complete list of bacterial endophytes isolated from a broad range of plants is provided by Rosenblueth and Martinez - Roncero (2006) and Berg and Hallmann (2006) which update the ground work laid by Hallmann et al., (1997) and Lodewyckx et al., (2002).

The endophytes such as Pleurostoma, Chaetomium, Coniochaeta, Daldinia, Xylaria, Hypoxylon, Nodulisporum, Cazia and Phellinus isolated from Hyperzia serrata were confirmed for the first time by rDNA ITS analysis (Chen, 2011).

\section{Surface sterilization}

To examine the efficiency of Sodium hypochlorite, Ethanol and Mercuric chloride as effective sterilizing agent and survival percentage of treated explants, and to detect the effect on explants treated individually and by the different combining of chemical disinfectant. Sterilization procedures that were at first selected and used were not found efficient agent individually.

However various combination and duration of $70 \%$ of Ethanol, $2 \%$ of Sodium hypochlorite and $0.1 \%$ of Mercuric chloride were applied to the explants to achieve a satisfactory result (Nawed Anjum et al., 2015)

The surface sterilization of plant parts with $70 \%$ of Ethanol for 1 minute, $2 \%$ of Sodium hypochlorite for 4 minutes and $0.1 \%$ of Mercuric chloride for 4 minutes, ethanol for 30 seconds finally 3 rinses in distilled water (Nawed Anjum et al., 2015).

\section{Isolation}

Many varieties of dicotyledonous plants were collected and transported to refrigerated box at $4^{\circ} \mathrm{C}$ to the laboratory. After surface sterilization, the sample extracts from plants made upto $10 \mathrm{ml}$ using sterile distilled water. From that, $1 \mathrm{ml}$ was taken and serially diluted using test tubes containing $9 \mathrm{ml}$ of sterilized distilled water. $0.1 \mathrm{ml}$ from the dilutions $10^{-5}$, $10^{-6}$ and $10^{-7}$ were transferred to petriplates containing Nitrogen free malate medium (NFB) (Dobereiner, 1992) and Kings'B medium (Kaare Johnsen and Preben Nielson 2006) for the isolation of Azospirillum and Pseudomonas species respectively.

Meanwhile, $1 \mathrm{ml}$ of extract was dissolved in semi solid NFB to observe the sub - surface pellicle formation by Azospirillum species and kept at room temperature. The separated colonies in petridish were bought to pure culture by several sub culture. Pellicle of Azospirillum species in test tubes containing semi solid NFB was streaked in petri plates containing semi solid NFB. The purified strains were maintained in Nutrient agar slant and stored at $4^{\circ} \mathrm{C}$ for future use.

\section{Molecular studies on endophytes}

The molecular characterization of endophytes was subjected to the purpose of identification at the molecular level which includes the metagenomic studies, use of molecular markers, molecular cloning and gene expression studies. Denaturing gradient gel electrophoresis (DGGE) profiles of 16s rRNA gene fragments amplified from total plant DNA were used to detect some non culturable endophytic bacteria by comparing the profile with the bands obtained from the culturable endophytes from citrus plants (Araujo, 2002).

Bacterial endophyte community of potato (Solanum tuberosum) was examined by using bacterial automated ribosomal intergenic 
spacer analysis (B-ARISA) technique (Marter, 2010). To determine the richness of bacterial operational taxonomic units (OTUS), the pyro sequencing was used. The author included that metagenomic analysis can complement PCR based analysis yield information on whole gene operons (Nikolic, 2011).

Molecular studies in endophytes have gone to the extent of complete genome in Enterobacter sp. An endophytic plant growth promoting gamma-proteo bacterium isolated from the stem of polar, a potentially important biofuel feed stock plant was sequenced (Taghavi, 2010).

In contrast to the extensive information on the molecular mechanism of bacteria - plant interactions (Lugtenberg et al., 2002) (Oldriyd and Dounie 2004). There is only limited data on the endophyte - host molecule interaction. By the presence of bacteria, plant genes may be modulated and the genes so expressed provide clues to the effects of endophytes in plants.

The gene expression in response to the endophytic colonization of Gluconacetobacter diazotrophicus and Herbaspirillum rubrisubalbicans are being studied in sugarcane (De Matos Nogueira et al., 2001).

\section{Isolation of DNA}

Around $0.5 \mathrm{ml}$ of sample was taken and placed in a morter and homogenized with 2 $\mathrm{ml}$ of extraction buffer.

The extraction buffer (PH 8.0) contains $100 \mathrm{~m}$ M Tris, $20 \mathrm{~m} \mathrm{M}$ EDTA, $0.5 \mathrm{M} \mathrm{NaCl}, 7 \mathrm{M}$ urea, $0.1 \% \beta$ - mercapto ethanol and 25 of SDS.

Take an equal volume of Phenol: Chloroform: Isoamyl alcohol $(25: 24: 1)$ was added to the tubes and mixed well by gently shaking the tubes.

The tubes are allowed to centrifuge at room temperature for 15 minutes at $15000 \mathrm{rpm}$. The upper aqueous phase (supernatant) was collected in a new tube and an equal volume of Chloroform: Isoamyl alcohol (24:1) was added and mixed.

The supernatant obtained after centrifuging at room temperature for 10 minutes at 15000 rpm was transferred to new tubes.

By adding 0.1 volume of $3 \mathrm{M}$ sodium acetate, $\mathrm{PH}-7.0$ and 0.7 volume of Isopropanol for the purpose of DNA precipitation. After the tubes were incubated for 15 minutes at room temperature, the tubes were centrifuged at $4^{\circ}$ $\mathrm{C}$ for 15 minutes at $15000 \mathrm{rpm}$.

The DNA pellet was washed with $70 \%$ ethanol for twice, then very briefly with $100 \%$ ethanol and allowed to air dry. Then the DNA was dissolved in TE (Tris $-\mathrm{cl} 10 \mathrm{~m} \mathrm{M} \mathrm{PH} \mathrm{=}$ 8.00 and EDTA $1 \mathrm{~m} \mathrm{M}$ ) to remove RNA 5 micro liter of DNAse from RNAse A $(10 \mathrm{mg} /$ ml) was added to the DNA (52).

\section{PCR analysis}

AP - PCR analysis: AP - PCR amplification was carried out in a volume of 25 micro liter containing 100ng of template DNA, $2 \mathrm{~m} \mathrm{M}$ $\mathrm{MgCl}_{2}, 5 \mu \mathrm{m} 27 \mathrm{f}$ primer, $2.5 \mu \mathrm{l}$ of $10 \mathrm{X}$ assay buffer which includes (10 m M Tris PH 9), 50 $\mathrm{m} \mathrm{M} \mathrm{Kcl,} 1.5 \mathrm{~m} \mathrm{M} \mathrm{Mgcl}$ and $0.01 \%$ Gelatin) $10 \mathrm{~m} \mathrm{M}$ each of dNTPS and 5 units/ $\mu \mathrm{l}$ of Taq DNA polymerase.

1 cycle of 5 minutes at $94^{\circ} \mathrm{C}$ for denaturation, 5 minutes at $45^{\circ} \mathrm{C}$ for annealing and 5 minutes at $72^{\circ} \mathrm{C}$ for extension and 35 cycles of 1 minute at $94^{\circ} \mathrm{C}, 1$ minute at $45^{\circ} \mathrm{C}$ and 1 minute at $72^{\circ} \mathrm{C}$ followed by a final 10 minutes extension at $72^{\circ} \mathrm{C}$. 
Table.1 Possible endophytes

\begin{tabular}{|c|c|c|}
\hline Plant type & Endophytes present in plants & Reference \\
\hline $\begin{array}{l}\text { Sugarcane } \\
\text { officinarum) }\end{array}$ & Herbaspirillum seropedicae & Dong et al., 1994 \\
\hline Corn (Zea mays) & $\begin{array}{l}\text { Enterobacter sp., Pseudomonas sp., } \\
\text { Klebsiella sp., Vibrio sp., }\end{array}$ & Fisher et al., 1992 \\
\hline Rice (Oryza sativa) & Azorhizobium caulinodans & Engelhard et al., 2000 \\
\hline Banana (Musa spp.,) & Citrobacter, Azospirillum brasilense & Martinez et al., 2003 \\
\hline Cotton (Gossypium spp.,) & $\begin{array}{lccc}\text { Agrobacterium } & \text { sp., } & \text { Serratia } & s p ., \\
\text { Burkholderia } & \text { sp., } & \text { Bacillus } & s p ., \\
\text { Staphylococcus, } & \text { Rhizobium } & s p ., \\
\text { Variovorax sp., } & \text { Pseudomonas } & s p ., \\
\text { Acenitobacter } & \text { sp., } & \text { Arthrobacter., } \\
\text { Enterobacter } & & \end{array}$ & MC Inroy and Kleopper, 1995 \\
\hline $\begin{array}{l}\text { Sweet potato (Ipomoea } \\
\text { batatas) }\end{array}$ & Enterobacter arburiae & Asis and Adachi 2003 \\
\hline $\begin{array}{l}\text { Tomato } \\
\text { lycopersicum) }\end{array}$ & Pseudomonadaceae & Samish et al., 1963 \\
\hline Carrot (Daucus carota) & Pseudomonas fluorescens & Surette et al., 2003 \\
\hline Citrus plant & 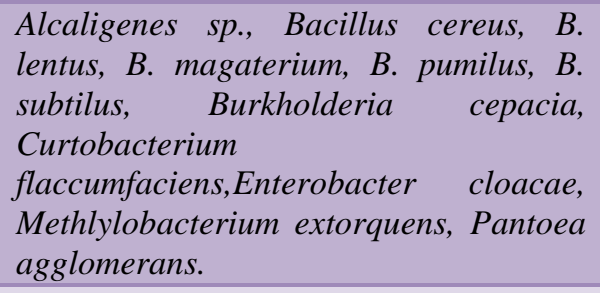 & Araujo et al., 2001 \\
\hline Soy bean (Glycine max L.,) & Klebsiella oxytoca & Kuklinsky - sobral et al., 2004 \\
\hline Cucumber (Cucumis sativus) & $\begin{array}{llll}\text { Pseudomonas } & \text { sp., } & \text { Bacillus } & s p ., \\
\text { Enterobacter sp., Arthrobacter } & s p ., \\
\text { Agrobacterium sp., Burkholderia } & s p ., \\
\text { Stenotrophomonas } & & s p ., \\
\text { Chryseobacteriumsp., } & & \\
\end{array}$ & Kloepper, 1983 \\
\hline Lettuce (Lactuca sativa) & Escherichia coli & Ingham et al., 2005 \\
\hline Yellow lupine, citrus plant & Burkholoderia cepacia & $\begin{array}{l}\text { Araujo et al., 2001, Barac et al., } \\
2004\end{array}$ \\
\hline $\begin{array}{l}\text { Alfalfa, carrot, raddish, } \\
\text { tomato }\end{array}$ & Salmonella entericia & $\begin{array}{l}\text { Cooley et al., 2003, Guo et al., } \\
\text { 2002, Islam } \text { et al., } 2004\end{array}$ \\
\hline Rice & Serratia marcescens & Gyneshwar et al., 2001 \\
\hline Wheat (Tritricum aestivum) & Azospirillum sp., & Webster et al., 1997 \\
\hline Rice (Oryza sativa) & Azoascus sp., Herbaspirillum sp., & $\begin{array}{l}\text { Reinhold-Hurek and Hurek, 1997, } \\
1998\end{array}$ \\
\hline Sugarcane, coffee & Gluconoacetobacter diazotrophicus & $\begin{array}{l}\text { Cavalcante and Dobereiner 1988, } \\
\text { Jimenez Salgado et al., } 1997\end{array}$ \\
\hline $\begin{array}{l}\text { Banana, rice, maize, } \\
\text { sugarcane }\end{array}$ & Klebsiella variicola & Rosenblueth et al., 2004 \\
\hline $\begin{array}{l}\text { Sugarcane } \\
\text { officinarum) }\end{array}$ & Herbaspirillum rubrisulbabicans & Olivares et al., 1996 (80) \\
\hline $\begin{array}{l}\text { Marigold } \quad \text { (Calendula } \\
\text { officinalis) }\end{array}$ & Microbacterium esteraromaticum & Sturz and Kimpinski 2004 (81) \\
\hline $\begin{array}{l}\text { Sweet potato (Ipomoea } \\
\text { batatas) }\end{array}$ & Paenibacillis odosifer & Reiter et al., 2003 (82) \\
\hline
\end{tabular}




\section{6s rRNA sequence determination}

The amplified products of approximately 1461 bp of Azospirillum sp and 1341 bp of Pseudomonas sp were detected and sequenced by $16 \mathrm{~s}$ primer containing $27 \mathrm{f}$ (forward primer) and 1492 (reverse primer). The sequencing products were purified and the results were observed.

Finally the sequence can be compared with sequence in the NCBI data bank using the BLAST program.

\section{Future research}

The most challenging sectors to climatic change are done by agriculture. Future research is to be focused on developing microbial formulation to boost plant performance under drought stress which reduces the chemical fertilizers and pesticides usage (Kaushal and Wani, 2015). Further studies at the molecular and biochemical levels are warranted to ascertain the protective role of these PGPB isolates against fungal pathogens.

Though some root endophytes are latent pathogens, many others (root endophytes) provide benefits to the plant growth by helping in phosphorus update and protecting against pests and diseases (Sieber, 2002).

\section{Possible endophytes}

The possible endophytes in various plants have been reported by scientists at different time period and a few such organisms have been listed in the table 1 .

\section{References}

Altschul, S.F., Gish, W., Miller, W., Myers, E.W. 1990 Basic local alignment search tool. J. Mol. Biol, 215, 403 410.
Araujo, W. L., Maccheroni, W., AguilarVildosa, C.I., Barrosa, P.A.V. 2001. Variability and interactions between endophytic bacteria and fungi isolated from leaf tissues of Citrus root stocks. Can J. Microbiol, 47: 229-236.

Araujo, W.L., Marcon, J., Maccheroni, W., Van Elsas, J.D., VanVuurde, J.W.L., Azevedo, J.L. 2002. Diversity of endophytic bacterial populationand their interaction with Xylella fastidiosa in citrus plants. Appl and Environ Microbiol, 68: 4906 - 4914.

Asis, C.A., Adachi, K. 2003. Isolation of endophytic diazotroph Pantoca agglomerans and Enterobacter asburiae from sweet potato stem in Japan. Lett. App. Microbiol, 38: 1923.

Auge, R.M. 2001. Water relations, drought and vesicular - arbuscular mycorrhizal symbiosis. Mycorrhiza, 11:3-42.

Azevedo, J.L., Maccheroni, W., Araujo, W.L., Pereira, J.O. 2001. Endophytic microorganisms; A review on insect control and recent advances on tropical plants. Electron. J. Biotechnol, 3(2), 40- 65.

Barac, T., Taghavi, S., Borremans, B., Provoost, A. 2004. Engineered endophytic bacteria improve phytoremediation of water-soluble, volatile, organic pollutants. Nat. Biotechnol, 22: 583-588.

Beijerinck, M.W. 1888. Cultur des Bacillus radicola aus den Knöllchen. Bot Ztg 46: 740-750.

Bilal, R., Rasul, G., Arshad, M., Malik, K.A. 1993. Attachment, colonization and proliferation of Azospirillum brasiliense and Enterobacter spp. on root surface of grasses. World $\mathbf{J}$ Microb Biot, 9:63-69.

Cavalcante, V.A., Dobereiner, J. 1988. A new acid tolerant nitrogen fixing bacterium associated with sugarcane. Plant-Soil, 108: 23-31.

Chareprasert, S., Piapukiew, J., Thieenhirum, S., Whalley A.J.S. 2006. Endophytic 
fungi of teak leaves Tectona grandis L and rain tree leaves samanea saman Merr. World J Microbiol Biot, 22(5): 481-486.

Chen, Y.X., Qi, Y.D., Wei, J.H. 2011. "Molecular identification of endophytic fungi" from medical plant Huperzia serrata based on rDNA ITS Analysis. World $\mathrm{J}$ of Microbiol and Biot, 27(3): 495 - 503.

Choluj, D., Karwowska, R., Jasinska, M., Haber, G. 2004. Growh and dry matter partitioning in suger beet plants (beta vullgaris L) under moderate drought. J. plant soil environ, 50: 265 - 272.

Cooley, M.B., Miller, W.G., Mandrell, R.E. 2003. Colonization of Arabidopsis thaliana with Salmonella enterica and enterohemorrhagic Escherichia coli 0157: H7 and competition by Enterobacter asburiae. Appl. Environ. Microbiol, 69: 4915-4926.

De Bary, A. Morphologie und Physiologie der Pilze, Flechten und Myxomyceten, 1866.

De Matos Nogueira, E., Vinagre, F., Masuda, H.P., Vargas, C. 2001. Expression of sugarcane genes induced by inoculation with Glucanacetobacter diazotrophicus and Herbaspirillum rubrisubalbicans. Genet. Mol. Biol, 24:199 - 206.

Dobereiner, J. 1992. Recent changes in concepts of plant bacterial interactions; Endophytic $\mathrm{N}_{2}$ fixing bacteria. Cienciae cultura, 44: $310-$ 313.

Dong, Z., Canny, M.J., MC Cully., Roboredo, M.R. 1994. Nitrogen fixing endophyte of sugarcane stems. Plant Physiol, 105: 1139-1147.

Egamberdiyeva, D., Hoflich, G. 2003. Influenza of growth promoting bacteria on the growth of wheat in different soil and temperatures. Soil Biol and Biochem, 35: 973 - 978.

Engelhard, M., Hurek, T., Reinhold- Hurek, B. 2000. Preferential occurrence of diazotrophic endophytes, Azoarcus spp., in the wild rice species and land races of Oryza sativa in the comparison with modern races. Environ. Microbiol, 2: 131-141.

Fisher, P.J, Petrini, O., Lappin, S.H.M. 1992. The distribution of some fungal and bacterial endophytes in maize (Zea mays L.,). New phytologist, 122: 299305.

Forchetti, G., Masciarelli, O., Alemano, S., Alvarez, D. 2007. Endophytic bacteria in sunflower (Helianthus annuus L.): isolation, characterization, and production of jasmonates and abscisic acid in cultural medium. Appl Microbial Biot, 76:1145-1152.

Galippe, V. Note. 1887. sur la présence de microorganisms dans les tissus végétaux. C.R Seances Soc Biol Fil, 39:410-416.

Guo, X., Van Iersel, M.W., Chen, J., Brackett, R.E. 2002. Evidence of association of Salmonella with tomato plants grown hydroponically in inoculated nutrient solution. Appl. Environ. Microbiol, 68: 3639-3643.

Gyneshwar, P., James, E.K., Mathan, N., Reddy, P.M. 2001. Endophytic colonization of rice by a diazotrophic strain of Serratia marcescens, J. Bacteriol, 183: 2634-2645.

Hallmann, 2001. J. Plant interactions with endophytic bacteria. In: Jeger, M.J., Spence, N.J (eds), Biotic interactions in plant-pathogen association. CAB International. Wallingford, 87-119

Hallmann, J., Berg, G., Schulz, B., Boyle, C. 2006. Isolation procedures for endophytic microorganisms. Microbial Root Endophytes Springer-Verlag, Berlin Heidelberg. Soil biol, 9: 299319

Hallmann, J., Quadt-Hallmann, A., Rodr'1guez-K'abana, R., Kloepper, J.W. 1998. Interactions between Meloidogyne incognita and endophytic bacteria in cotton and cucumber. Soil Biol Biochem, 30: 925-937 
Hallmann, J.A., Quadt - Hallmann, Mahaffee W.F., Kleopper, J.W.1997. 'Bacterial endophytes in agricultural crops', Canadian J of Microbiol, 43(10) 895 914.

Hata, K., Atari, R., Stone, K. 2008. Isolation of endophytic fungi from leaves of Neolistsea sericea in broad leaf and conifer stands, Myco science, 49(4): $229-232$.

Hayward, A.C.1974. Latent infections by bacteria. Annu. Rev. Phytopathol 12:87-97.

Hennig, K., Villforth, F. 1940. Experimentelle untersuchungenzur frage der bacteria symbiose in hoheren pflanzen und ihrebeeingflussung durchl leitemente. Biochem. Zeitschr 305:299-309.

Hooper, L.V., Wong, M.H., Thelin, A., Hansson, L. 2001. Molecular analysis of commensal host-microbial relationships in the intestine. Science, 291:881-884.

Hyde, K., Soytong, K. 2008. The fungal endophyte dilemma. Fungal Divers, 33.

Idris, E.E., Iglesias, D.J, Talon, M., Borriss, R. $2007 . \quad$ Tryptophan-dependent production of indole-3-acetic acid (IAA) affects level of plant growth promotion by Bacillus amyloliquefaciens FZB42. Mol Plant Microbe Interact, 20:619-26.

Ingham, S.C., Franslau, M.A., Engel, R.A., Breuer, J.R. 2005. Evaluation of fertilization to planting and fertilization to harvest intervals for safe use of non-composted bovine manure inn Wilconsin vegetable production. J. Food. Pot, 68: 11341142

Islam, M., Morgan, J., Doyle, M. P., Phatak, S. C., Millner, P. 2004. Fate of Salmonella enterica serovar Typhimurium on carrots and radishes grown in fields treated with contaminated manure composts or irrigation water. Appl. Environ. Microbiol, 70: 2497-2502.
Javed, M., Arshand, M. 1997. Growth promoting of two wheat cultivars by plant growth promoting rhizobacteria. Pakistan J Bot, 29: 243-248.

Jimenez-Salgado, T., Fuentes-Ramirez, L.E., Tapia-Hernandez, A., MascaruaEsparza, M.A., Coffeaarabica I. 1997. A new host plant for Acetobacter diazotrophicus Isolation of other nitrogen-fixing acetobacteria. Appl. Environ. Microbiol, 63: 3676-3683.

Kaare Johnsen, Preben Nielsen. 2006. Diversity of Pseudomonas strains isolated with Kings' $B$ medium and Gould's SI agar determined by respective extragenic palindromicpolymerase chain reaction, $16 \mathrm{~s} r$ DNA sequencing and Fourier transform infrared spectroscopy characterization. Microbiology letters, Vol 173 Issue 1.

Kaushal, M., Wani, S.P. 2015. Plant growth promoting Rhizobacteria: drought stress alliviators to amiliroate crop production in dry lands. Ann. Microbiol, 1- 8.

Kloepper, J.W. 1983. Effect of seed pieces inoculation with plant growth promoting rhizobacteria on populations of Erwinia carotovora on potato roots and daughter tubers. Phyto pathology, 73(92): $217-219$

Kobayashi, D.Y., Palumbo, J.D. 2000. Bacterial endophytes and their effects on plants and uses in agriculture. In; Bacon, White C.W. J.F(eds). Microbial endophytes. Marcel Dekker, New York, USA, 199 - 233.

Konnova, S.A., Brykova, O.S., Sachkova, O.A., Egorenkova, I.V. 2001. Protective role of the polysaccharide containing capsular components of Azospirillum brasilense. Microbiology, 70: 436 - 440.

Kuklinsky-Sobral, J., Araujo, W.L., Mender, R., Geraldi, I.O. 2004. Isolation and characterization of soybean associated bacteria and their potential for Plant growth promotion. Environ. Microbiol, 6: 1244-1251. 
Lodewyckx, C., Vangronsveld, J., Porteous, F., Moore, E.R.B. 2002. Endophytic bacteria and their potential applications. Crit Rev plant Sci, 21: $583-606$.

Lugtenberg, B.J.J., Chin-A-Woeng, T.F.C., Blomberg, G.V. 2002. Microbes plant interactions; principles and mechanisms. Antonie van Leeuwenhoek, 81: 373 - 383.

Lund, B.M., Wyatt, G.M. 1972. The effect of oxygen and carbon di oxide concentrations on bacterial soft rots of potatoes.1.King Edword Potatoes inoculated with Erwinia carotovora var. atroseptica. potato.Res, 15: 174179.

Maren, L., Friesen Stephanie, S., Porter Scott, C., Stark, Eric, J. 2011. Microbially mediated plant functional traits. Annual Review of Eco. Evoland Systematics, 42: 23 -46.

Marter, D.K., Delgado, J.A., Holm, D.G., Stong, R.A. 2010. Pyro sequencing reveals a highly diverse and cultivar specific bacterial endophyte community in potato roots. Microbial ecology, 60: 157 - 166.

Martinez, L., Caballero - Mellado, J., Orozcoy, J., Martinez - Romero E. 2003. Diazotrophic bacteria associated with banana (Musa sp) Plant soil, 257; $35-47$.

MC Inroy, J.A., Kleopper, J.W. 1995. Survey of indigenous bacterial endophytes from cotton and sweet corn. Plant Soil, 173: 337-342.

Miche, L., Balandreau, J. 2001. Effects of rice seed surface sterilization with hypochlorite on inoculated Burkholderia vietnamiensis. Appl Environ Microbiol, 67: 3046 - 3052.

Nawed Anjum, Ramesh Chandra.2015. Isolation of endophytes, Asian Journal of Pharmaceutical and Clinical Research, vol.8.

Nikolic, B.H., Schwab, Sessitsch, A. 2011. Metagenomic analysis of the 1- amino - cyclopropone 1- carboxylate deaminase gene(acdS) operons of an un cultured bacterial endophyte colonizing Solanum tuberosum L, Archives of Microbiology, 193: 665 676 ,

Oldriyd, G.E.D., Dounie, J.A. 2004. Calcium, kinases and nodulation signaling in legumes. Nat.Rev.Mol.CellBiol, 5: $566-576$.

Olivares, F.L., Baldani, V.L.D., Reis, V.M., Baldani, J.L. 1996. Occurence of endophytic diazotrophs Herbaspirillum spp. In roots, stems and leaves, predominantly of Gramineae. Biol. Fertil. Soils, 21: 197200.

Perotti, R. 1926. On the limits of biological enquiry in soil science. proc intern. soc. soil. sci, 2:146-161.

Rahadari, P., Hoseini, S.M. 2012. Drought stress, A review. Int. J. Agron. plant prod. 3: 443-446.

Rai, R., Dash, P.K., Prasanna, B.M., Singh, A. 2007. "Endophytic bacterial flora in the stem tissue of a tropical maize" (Zeamays L) genotype : isolation, identification and enumeration, World $\mathrm{J}$ of Microbiol Biotech, 23(6): 853 858.

Reinhold, B., Hurek, Hurek, T. 1998. "Life in grasses; Diazotrophic endophytes", Trends in microbiol, 6(4): 139 - 144.

Reinhold-Hurek, B., Hurek, J. 1997. Azoarcus spp. And their interactions with grass roots. Plant soil, 194: 57-64.

Reiter, B., Burgmann, H., Burg, K., Sessitsch, A. 2003. Endophytic nif $H$ gene diversity in African sweet potato can. J. Microbiol, 49: 549-555.

Roberson, E.B., Firestone, M.K. 1992. Relationship between desiccation and exo-polysaccharide production in soil Pseudomonas sp. Appl. Environ. Microbial, 58: 1284 - 1291.

Rosenblueth, M., Martinez - Romero, E. 2004. Rhizobium etli maize populations and their competitiveness for root colonization, Arch Microbiol, 181: $337-344$. 
Rosenblueth, M., Martinez - Romero, E. 2006. Bacterial endophytes and their interactions with hosts. Mol plant Microbes Interact, 19: $827-837$.

Rosenblueth, M., Martinez, L., Silva, J., Martinez-Romero, E. 2004. Klebsiella variicola, a novel species with clinical and plant associated isolates. Syst. Appl. Microbiol, 27: 27-35.

Sambrook, J., Russell, D.W. 2001. Molecular Cloning: A Laboratory Manual, Vol.1, Cold Spring Harbor, New York.

Samish, Z., Etinger-Tulczynska, R., Bick, M. 1963. The microflora within the tissue soft fruit and vegetables. J. Food Science, 28: 259-266.

Schulz, B., Boyle, C. 2005. The endophytic continuum. Mycol. Res.109: 661 686.

Seghers, D., Wittebolle, L., Top, E.M., Verstraete, W. 2004. Impact of agricultural practices on the Zeamays L. endophytic community Appl. Environ. Microbial, 70: 1475- 1482.

Shekhawat, G.S., Piplani, S., Ansari, M.M. 1984. Endophytic bacterial flora of potato plant in relation to soft rot disease. Indian Phytopathol. 37: 501505.

Sieber, T.N.2002. Fungal root endophytes. In Y Waisel, A Eshel and U kafkafi plant roots; The hidden half, New York Basel ; Marcel Dekker, 887 - 917.

Staddon, P.L. 2004. Carbon isotopes in functional soil ecology. Trends in Ecology and Evolution, 19:148-154

Staddon, P.L., Thompson, K., Jakobsen, I., Grime, J.P. 2003c. Mycorrhizal fungal abundance is affected by long-term climatic manipulations in the

\section{How to cite this article:}

Premalatha Ramasamy, Yuvarani Sethuram, Usha Nandhini Selvaraj, Durgha Srinivasan and Vijayaraghavan Ramasamy. 2019. Defendable Agricultural Boost by Profiteering Endophytes. Int.J.Curr.Microbiol.App.Sci. 8(04): 1386-1397. doi: https://doi.org/10.20546/ijcmas.2019.804.161 field. Global Change Biology, 9: 186194.

Stone, J.K., Bacon, C.W., White, J. 2000. An overview of endophytic microbes. endophytism defined. In Bacon, C.W, White, J.(ed), Microbial endophytes. Taylor \& Francis, New York, NY. 329.

Strobel, G., Daisy, B., casitllo, U., Harper, 2004 J. Natural products from endophytic microorganisms. Nat. prod, 67: 257-268.

Sturz, A., Kimpinski, J. 2004. Endo root bacteria derived from marigold (Tagetes spp.,) can decrease soil population densities of root lesion nematodes in the potato root zone. Plant. Soil, 262: 241-249.

Surette, M.A., Sturz, A.V., Lada, R.R., Nowak, J. 2003. Bacterial endophytes in processing carrots (Daucuscarata $L$. Varsativas) their localization, population density, biodiversity and their effects on plant growth plant soil, 253: 381-390.

Taghavi, S., Van der Lelie, D., Hoffman, A. 2010. Genome sequence of the plant growth promoting endophytic bacterium Enterobacter sp., PLOS Genetics, 6(5): Article ID C 1000943.

Thongsandee, W., Matsude, Y., Ito, S. 2012. Temporal variations in endophytic fungal assemblages of Ginkgo biloba (L). J. of Forest Research, 17(2) 213 218.

Webster, G., Gough, C., Vasse, J., Batchelor, C.A. 1997. Interactions of rhizobia with rice and wheat plant soil, 194: 115-122. 